\title{
Evaluation of toxic metal levels in edible tissues of three wild captured freshwater fishes
}

\author{
Katya PEYCHEVA*; Lubomir MAKEDONSKI, Albena MERDZHANOVA and Mona STANCHEVA \\ Department of Chemistry, Faculty of Pharmacy, Medical University of Varna, 55 Marin Drinov Str., 9000 Varna
}

\begin{abstract}
River ecosystems are vulnerable to heavy metal pollution. Fish samples are considered as one of the most indicative factors, in fresh water systems, for the estimation of trace metals pollution potential since they are the final chain of aquatic web. The objective of the present study is to evaluate the concentration of some toxic elements (As, $\mathrm{Hg}, \mathrm{Pb}, \mathrm{Cd}$ and $\mathrm{Ni}$ ) in edible part of three wild fresh water fish species (zander (Sander lucioperca), wels catfish (Silurus glanis) and European carp (Cyprinus Carpio)) caught from Bulgarian part of Danube river collected during 2010. The Danube River is the European Union's longest and the continent's second longest river that passes through or touches the borders of ten countries. It has a great importance in regard to biodiversity, economics and transportation. The elements ( $\mathrm{As}, \mathrm{Pb}, \mathrm{Cd}$ and $\mathrm{Ni}$ ) were assayed using Perkin Elmer Zeeman 3030 electrothermal atomic absorption spectrometer with an HGA-600 atomizer. Determination of $\mathrm{Hg}$ was performed using Milestone Direct Mercury Analyzer DMA-80. The results were expressed as $\mu \mathrm{g} / \mathrm{g}$ dry weight. The order of heavy metal accumulation in the edible part of zander is $\mathrm{As}>\mathrm{Hg}>\mathrm{Pb}>$ $\mathrm{Ni}>\mathrm{Cd}$ while the other two fish species show a different metal accumulation $\mathrm{Hg}>\mathrm{As}>\mathrm{Pb}>\mathrm{Ni}>\mathrm{Cd}$. In all heavy metals, the accumulation of mercuric and arsenic proportion was significantly high in all three fish types.
\end{abstract}

Keywords: Danube River, fish, toxic elements, ETAAS, Mercury Analyzer

\section{Introduction}

Heavy metal pollution in rivers has become a matter of great concern, not only because of the threat it poses to public water supplies, but also because of the hazard to human consumption of fishery resources [1]. The Danube is the second largest river in Europe with the length of $2826 \mathrm{~km}$ passing through four Central European capitals before emptying into the Black Sea via the Danube Delta in Romania and Ukraine. The Danube River Basin collects water from nineteen countries [2], and it is subjected to large amounts of waste water input [3].

From the Danube, the Black Sea annually receives 240 tons of cadmium, 4000 tons of lead and 900 tons of chromium [4] One of the most affected zones is the north-western sector of the Black Sea, where the Danube delta is situated and where the river water and sediment discharge carry an unusually high amount of pollutants into the sea [5]
Fish represent one of the most indicative factors for the estimation of trace metals pollution potential [6] and this is important not only for the protection of the environment, but also for the fish quality. Fishes are well known to be excellent dietary sources of essential fatty acids such as omega 3 polyunsaturated fatty acids (n-3 PUFA) [7].Fish respond sensitively to an increase of concentration of contaminants (metals, organic pollutants) in water. The accumulation level of metals in organs and tissues of fish depends upon taxonomic belonging of the fish species, age patterns, their physical-biochemical characteristics and chemical status of the environment they live [8]. The advantages of using fish in biomonitoring programs are the following: they are good indicators of longterm (several years) effects and broad habitat conditions because they are relatively long-lived and mobile; they are easy to collect and identify to the species level; fish tend to integrate effects of lower 
trophic levels and thus fish assemblage structure is reflective of integrated environmental health [9].

Heavy metals can be classified as potentially toxic (arsenic, cadmium, lead, mercury, nickel etc.), probably essential (vanadium, cobalt) and essential (copper, zinc, iron, manganese, selenium) [10].Toxic elements can be very harmful even at low concentration when ingested over a long time period. The essential metals can also produce toxic effects when the metal intake is excessively elevated $[11,12]$ Fishery has a long tradition and commercially availability in Bulgaria. Fish consumption in Bulgaria is traditionally low compared to the levels of consumption in the neighboring countries. The low level of consumption of fish and fish products has a strong negative impact on fishing and aquaculture production. Fish consumption reached $6 \mathrm{~kg} / \mathrm{capita}$ annually in the middle of 1980s. In the 1990s, however, it plummeted to $3 \mathrm{~kg} /$ capita. During the last few years there is a tendency of slow increase of fish consumption in Bulgaria reaching $4.6 \mathrm{~kg}$ per capita in 2008.

One of the most important species for fishing in inland water basins including River Danube are the common carp (Cyprinus carpio) $(5,4 \%)$, wels catfish (Silurus glanis) or european catfish $(7,7 \%)$ and zander (Sander lucioperca) or pikeperch $(3,9 \%)$. The common carp has by far the most significant contribution (ca. $43 \%$ of the volume of the catches).

The objective of the present study is to evaluate the concentration of some toxic elements (As, $\mathrm{Hg}, \mathrm{Pb}, \mathrm{Cd}$ and $\mathrm{Ni}$ ) in edible part of three wild freshwater fish species (zander, wels catfish and european carp) caught from Bulgarian part of Danube river collected during 2010.

\section{Experimental}

\subsection{Sampling}

Three fish species were collected near town of Silistra $\left(44^{\circ} 7^{\prime} 20.66^{\prime \prime} B \quad 27^{\circ} 15^{\prime} 40.16^{\prime \prime L}\right)$ on the Bulgarian side of Danube River during 2010 (Fig.1).

These wild freshwater fish species are zander (Sander lucioperca), wels catfish (Silurus glanis) and European carp (Cyprinus Carpio). Total length and weight of the sample brought to laboratory on ice after collection were measured to the nearest millimeter and gram before dissection (Table 1).

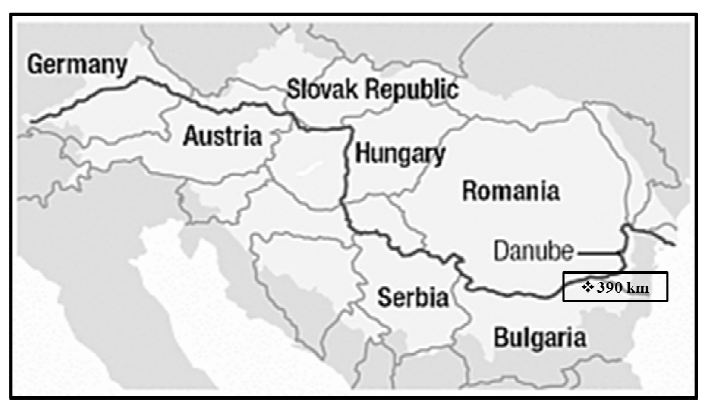

Fig. 1. The map of sampling locations in the Bulgarian side of Danube River basin

Only fillets of edible part of each individual were collected and included in the respective composite samples. Approximately $1 \mathrm{~g}$ sample of muscle from each fish were dissected, washed with distilled water, weighted, packed in polyethylene bags and stored at $-18^{\circ} \mathrm{C}$ until chemical analysis.

Table 1. Biometric data (mean \pm SE) of fish from the coastal waters of the Bulgarian Black Sea

\begin{tabular}{|c|c|c|c|c|}
\hline Sample & $\begin{array}{c}\text { Sampling } \\
\text { season, } \\
\text { year }\end{array}$ & $\mathbf{N}$ & $\begin{array}{c}\text { Weight } \\
(\mathbf{g}) \pm \boldsymbol{S D}\end{array}$ & $\begin{array}{c}\text { Length (cm) } \\
\mathbf{\pm} \boldsymbol{S} \boldsymbol{D}\end{array}$ \\
\hline $\begin{array}{c}\text { Zander } \\
\text { (Sander } \\
\text { lucioperca) }\end{array}$ & $\begin{array}{c}\text { Autumn } \\
2010\end{array}$ & 3 & $\begin{array}{c}2034.1 \pm \\
32.2\end{array}$ & $54.3 \pm 0.6$ \\
\hline $\begin{array}{c}\text { Wels catfish } \\
\text { (Silurus } \\
\text { glanis) }\end{array}$ & Spring 2010 & 3 & $\begin{array}{c}2945.3 \pm \\
18.4\end{array}$ & $49.3 \pm 1.4$ \\
\hline $\begin{array}{c}\text { European } \\
\text { carp }\end{array}$ & Autumn & 3 & $3125.4 \pm$ & $56.4 \pm 5.4$ \\
(Cyprinus & 2010 & & 26.5 & \\
Carpio) & & & & \\
\hline
\end{tabular}

\subsection{Reagents and standard solutions}

All solutions were prepared with analytical reagent grade chemicals and ultra-pure water (18 $\mathrm{M} \Omega \mathrm{cm}$ ) generated by purifying distilled water with the Milli-QTM PLUS system. $\mathrm{HNO}_{3}$ was of suprapur quality was purchased from Fluka ${ }^{\circledR}$, Germany. All the plastic and glassware were cleaned by soaking in $2 \mathrm{M} \mathrm{HNO}_{3}$ for $48 \mathrm{~h}$, and rinsed five times with distilled water, and then five times with deionised water prior to use. The stock standard 
solutions of $\mathrm{Cd}$, As, $\mathrm{Ni}$ and $\mathrm{Pb}\left(1000 \mu \mathrm{g} \mathrm{mL}^{-1}\right)$ were Titrisol, Merck in $2 \% \mathrm{v} / \mathrm{v} \mathrm{HNO}_{3}$ and were used to prepare calibration standards.

\subsection{Sample digestion}

Fish samples are thoroughly washed with MQ water. The fish specimens were dissected and samples of fish fillets quickly removed and washed again with MQ water. To assess the total metal contents, microwave assisted acid digestion procedure was carried out. Microwave digestion system "Multiwave", "Anton Paar" delivering a maximum power and temperature of $1000 \mathrm{~W}$ and $300{ }^{\circ} \mathrm{C}$, respectively, and internal temperature control, was used to assist the acid digestion process. (Table 2):

Table 2: Microwave digestion system general parameters

\begin{tabular}{|l|l|}
\hline \multicolumn{2}{|c|}{$\begin{array}{c}\text { Microwave digestion system "Multiwave", } \\
\text { "Anton Paar" Acid mixture }\end{array}$} \\
\hline $\mathrm{HNO}_{3}$ & $6.5 \mathrm{~mL}$ \\
\hline Temperature (max) & $30{ }^{\circ} \mathrm{C}$ \\
\hline Pressure (max) & $75 \mathrm{bar}$ \\
\hline Quartz vessels & $\mathrm{HQ} 50$ \\
\hline Sample amount & $1 \mathrm{~g}$ \\
\hline Final volume & $10 \mathrm{~mL}$ \\
\hline
\end{tabular}

Reactors were subjected to microwave energy at $800 \mathrm{~W}$ in five stages program described below (Table 3).

Table 3: Microwave digestion system operational parameters

\begin{tabular}{|c|c|c|c|c|}
\hline Step & $\begin{array}{c}\text { Initial } \\
\text { power } \\
(\mathbf{W})\end{array}$ & $\begin{array}{c}\text { Time } \\
(\mathbf{m i n})\end{array}$ & $\begin{array}{c}\text { Final } \\
\text { power } \\
(\mathbf{W})\end{array}$ & Fan \\
\hline 1 & 100 & 5 & 600 & 1 \\
\hline 2 & 600 & 5 & 600 & 1 \\
\hline 3 & 600 & 5 & 800 & 1 \\
\hline 4 & 800 & 15 & 800 & 1 \\
\hline 5 & 0 & 15 & 0 & 3 \\
\hline
\end{tabular}

Determination of As was performed using Electrothermal AAS carried out on a Perkin Elmer (Norwalk, CT, USA) Zeeman 3030 spectrometer with an HGA-600 atomizer. Pyrolytic graphitecoated graphite tubes with integrated platforms were used as atomizers (Table 4).

Determination of $\mathrm{Hg}$ was done by Milestone Direct Mercury Analyzer DMA-80 (Fig. 2).

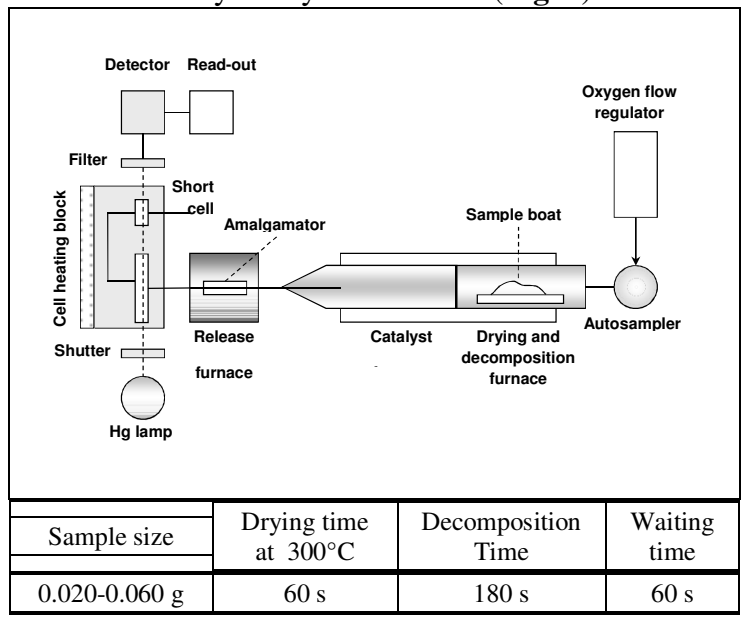

Fig 2: Total mercury determination in fish by DMA80

A Dorm-2 certified dogfish tissue was used as the calibration verification standard. Recoveries between $90 \%$ and $110 \%$ were accepted to validate the calibration. All specimens were run in batches that included blanks, a standard calibration curve, two spiked specimens, and one duplicate. The results showed good agreement between the certified and the analytical values, the recovery of elements being partially complete for most of them

\subsection{Statistical analysis}

The whole data were subjected to a statistical analysis. Student's-test was employed to estimate the significance of values.

\section{Results and Discussions}

Heavy metal concentration in each of the three analyzed fish species are presented in Fig. 3, 4 and $\mathbf{5}$. Heavy metal analysis has shown that $\mathrm{As}, \mathrm{Hg}, \mathrm{Cd}, \mathrm{Pb}$ and $\mathrm{Ni}$ concentrations were below detection threshold in all analyzed samples.

The accumulation patterns tend to vary among species based on their behavior and feeding habits [12] which are in accordance with the results in this study. 
Table 4: Instrumental parameters for HGA 600

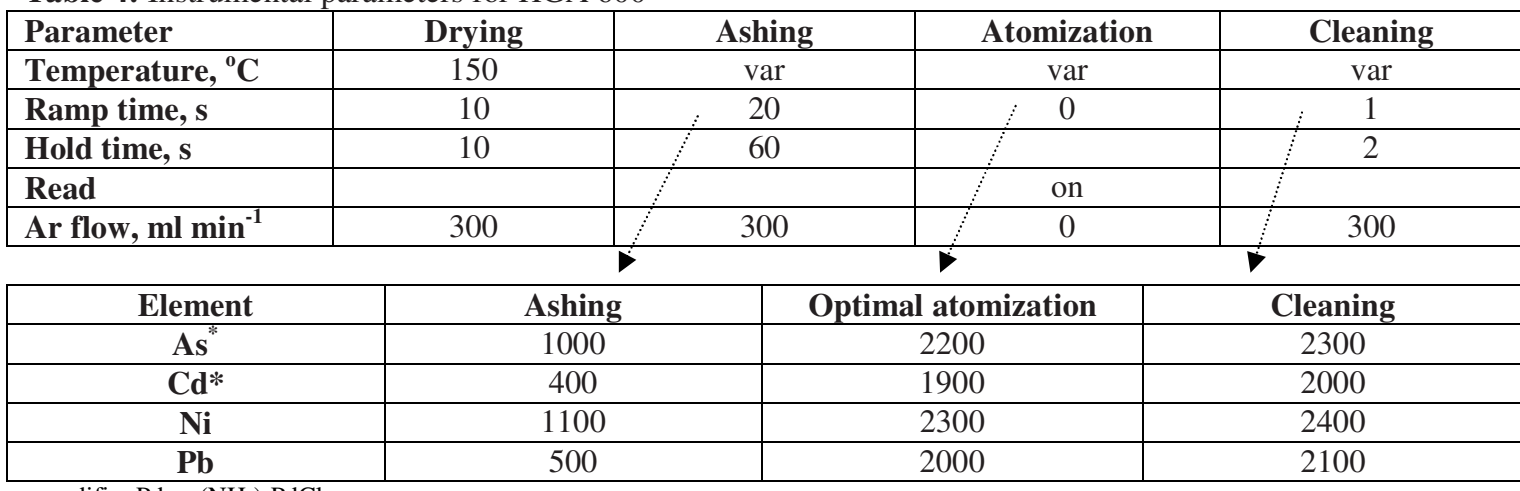

- modifier $\mathrm{Pd}$ as $\left(\mathrm{NH}_{4}\right)_{2} \mathrm{PdCl}_{4}$

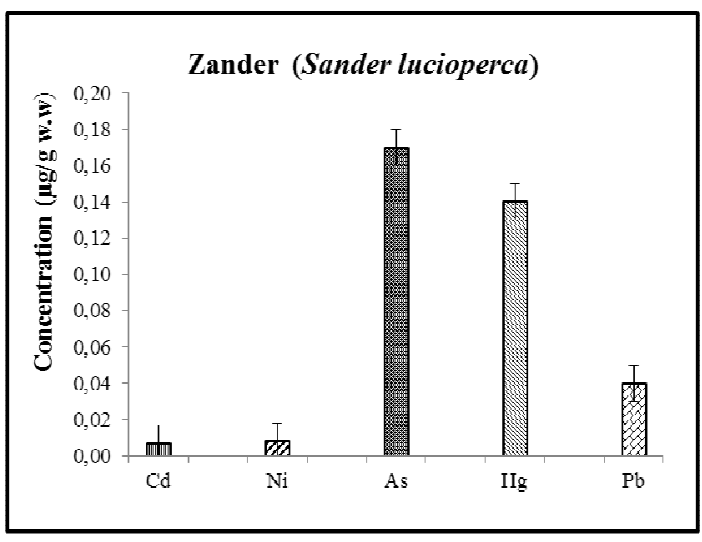

Fig 3. The mean heavy metal concentration $(\mathrm{mg} / \mathrm{kg}$ w.w \pm SD) in the tissues of zander

Wels catfish had the lowest concentrations of assessed elements in edible tissues when compared with other analyzed species, which might be explained with its different behaviour patterns. Wels catfish is prefominantly a nocturnal species. During daytime, it is consistently situated in a littoral zone, where it spends extended periods of time hided in concealed habitats [14].

European carp on the other hand are mainly bottom dwellers but search for food in the middle and upper layers of the water body Carp are omnivorous, with a high tendency towards the consumption of animal food, such as water insects, larvae of insects, worms, mollusks and zooplankton.

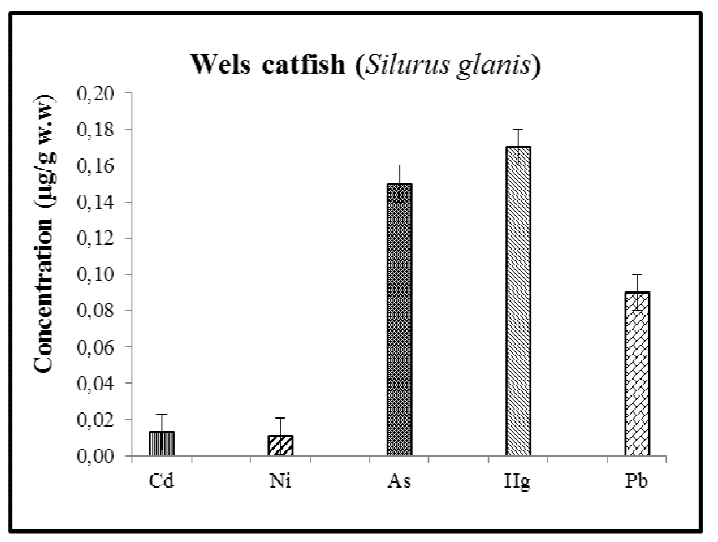

Fig 4. The mean heavy metal concentration $(\mathrm{mg} / \mathrm{kg}$ $\mathrm{w} . \mathrm{W} \pm \mathrm{SD}$ ) in the tissues of wels catfish

Zander is a very aggressive wandering piscivorous predator also feed on zooplankton, zoobenthos, and fodder fish species. Zander forages in open waters and is seldom found in vegetated littoral zone [14] while carp occupies all types of aquatic habitats [15]. Both species have relatively similar diets, which might be a reason for similar elemental accumulation patterns observed significantly higher $\mathrm{Hg}$ concentration in edible tissues of european carp and wels catfish might be caused by its specific physiology. This is an accordance with the results of Subotic et al.[16] and Kenšova et al.[17]. It may be concluded from the results obtained that the highest mercury 
concentrations were found in fish of predatory species.

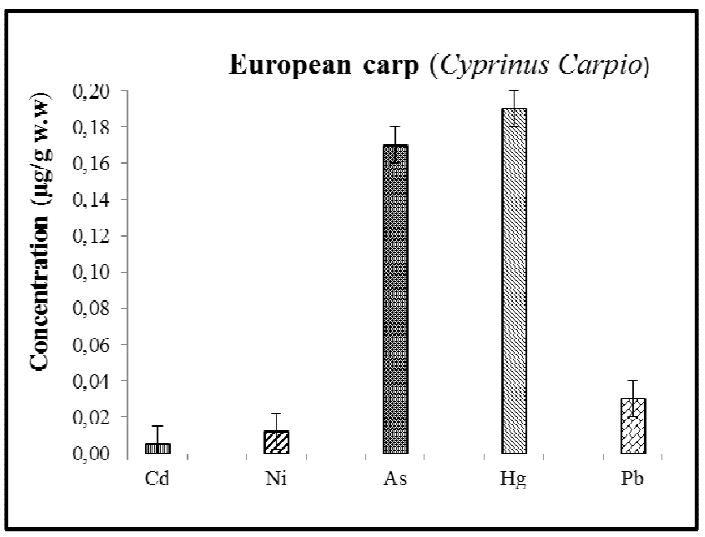

Fig 5. The mean heavy metal concentration $(\mathrm{mg} / \mathrm{kg}$ $\mathrm{w} . \mathrm{W} \pm \mathrm{SD}$ ) in the tissues of wels catfish

Many authors have noted higher mercury concentrations in predatory fish species $[18,19,20$, 21]. The mercury burden in predatory fish is greater. Because of poor mercury biodegradability in body tissues, $\mathrm{Hg}$ concentrations increase with the higher position of the species in the food chain [19]. Predatory fish, particularly older (6-12 years of age) and heavier individuals, may serve as a suitable indicator of mercury contamination in the given biotope [22]. From among non-predatory fish species, the lowest mercury concentrations were found in wels catfish. The maximum $\mathrm{Hg}$ level permitted is $0.5 \mathrm{mg} / \mathrm{kg}$ for fishe meat according to Bulgarian Food Authority [23] while the the Joint FAO/WHO [24] Expert Committee on Food Additives establishes a provisional tolerable weekly intake (PTWI) for total $\mathrm{Hg}$ as $300 \mu \mathrm{g} \mathrm{Hg}$ per person body weight.

Contrary to mercury, cadmium concentrations do not show any increases along the food chain in surface water ecosystems. For that reason zooplankton, and in particular zoobenthos, are much better bioindicators of contamination [19]. In fact, in predatory fish higher concentrations of cadmium are sometimes found than in nonpredatory fish species. The highest and lowest concentrations were found in the wels catfish and the carp, respectively. This result is controversial to the results obtained by other authors [17] who explained it by the fact that cadmium is mostly accumulated in zooplankton and especially in zoobenthos, which make up the trophic basis of the nonpredatory fish species analyzed.

Lead concentrations in the tissue of the analyzed fish species show that the highest lead concentrations were found in tissues of wels catfish while the lowest lead concentrations were found in the muscle tissues of European carp. It was established that lead concentrations, same as cadmium and contrary to mercury concentrations, do not increase along the food chain in surface water ecosystems. Svobodová et al. [19] even noted a tendency towards lower lead concentrations in fish tissues along the food chain. They found the highest lead concentrations in zooplankton and zoobenthos, which are the trophic basis for non-predatory fish. Our results are not in agreement with this statemnet . Same trends are investigated by Altindağ et al. [25] in four fish species from lake Beyşehir, Turkey (max $\mathrm{Pb}$ concentration for L. lucioperca $-0.687 \mu \mathrm{g} / \mathrm{g}$, and min $\mathrm{Pb}$ concentration for C.carpio- $0.303 \mu \mathrm{g} / \mathrm{g}$.

Arsenic is ubiquitous in nature and humans are subject to numerous exposure sources: environmental, dietary, occupational, accidental etc. There is a great concern about exposure of very large human populations (many millions) to elevated As doses, mainly from natural sources such as contaminated drinking water [26, 27] and marine derived food products [28, 29]. Seafood could be a major source of total arsenic exposure for man, since it contains $\mathrm{mg} \mathrm{kg}^{-1}$ Toxicity of different As species in marine samples is highly dependent on their oxidation states and chemical forms. According to European Commission Regulation (1881/2006/EC) the maximum acceptable concentrations (MAC) for $\mathrm{Cd}$ and $\mathrm{Pb}$ in fish meat are $0.05 \mu \mathrm{g} / \mathrm{g}$ and $0.2 \mu \mathrm{g} / \mathrm{g}$ fresh weights, respectively. National regulation of Republic of Bulgaria prescribed 0.2, 0.05, 0.5 and 5 $\mathrm{mg} / \mathrm{kg}$ wet weight as MAC for $\mathrm{Pb}, \mathrm{Cd}$, Ni and As. In order to compare data obtained in this study with prescribed MAC, all concentrations were transformed from $\mu \mathrm{g} / \mathrm{g}$ to $\mathrm{mg} / \mathrm{kg}$. In analyzed fish species As concentration did not exceed prescribed MAC. Furthermore the concentration of $\mathrm{Ni}, \mathrm{Cd}$ and $\mathrm{Pb}$ were below national MAC and below EU MAC in all muscle samples. 


\section{Conclusions}

In this study the concentrations of five heavy metals are estimated in three wild captured freshwater fishes. They are in the range of $0.005-$ $0.013 \mathrm{mg} / \mathrm{kg}$ w.w for $\mathrm{Cd}, 0.008-0.012 \mathrm{mg} / \mathrm{kg}$ w.w for $\mathrm{Ni}, 0.15-0.17 \mathrm{mg} / \mathrm{kg} \mathrm{w.w} \mathrm{for} \mathrm{As,} \mathrm{0.14-0.19}$ $\mathrm{mg} / \mathrm{kg} \mathrm{w} . \mathrm{w}$ for $\mathrm{Hg}$ and $0.03-0.09 \mathrm{mg} / \mathrm{kg} \mathrm{w} . \mathrm{w}$

Numerous studies were focused on pollution in different commercially important fish species, especially on those that represent and important part of human diet. In that sense, our study provides valuable information for the studied fish species especially because these fish species represent major object of commercial fishery in the Danube River in Bulgaria. Analysis performed in this study revealed the existence of differences in concentrations of the assessed elements among species. Concentrations of $\mathrm{Pb}, \mathrm{Cd}, \mathrm{As}, \mathrm{Ni}$, and $\mathrm{Hg}$ were below maximum acceptable concentrations in all analyzed muscle samples, which indicates that the meat of studied species should be safe for utilization in human diet.

\section{References}

* E-mail address: peytcheva@ hotmail.com

[1]. B.F. Terra, F.G. Araujo, C.F. Calza, R.T Lopes and T.P. Teixeira, Water Air Soil Pollution 187, 275-284 (2008)

[2]. N. Sommerwerk, T. Hein, M. Schneider-Jakoby, C. Baumgartner, A. Ostojić, M. Paunović, J. Bloesch, R. Siber and Tockner Rivers of Europe, Elsevier Amsterdam, The Netherlands, pp 59-112 (2009)

[3]. N.Teodorović, S.Đukić, B.Maletin, N.Miljanovic and N.Jugovac, Tiscia 32, 55-60 (2000)

[4]. D. Secrieru and A. Secrieru, Estuar. Coast. Shelf Science 54, 513-526 (2002)

[5]. *** Marine Pollution '90, Action Programme, Swedish Environment Protection Agency, Solna, 165 (1990)

[6]. E. Alhas, S. Ahmet Oymak and H. Karadede Akin, Environ. Monit. Assess. 148, 11-18 (2009)

[7]. A. Merdzhanova, M. Stancheva and L. Makedonski, Ovidius University Annals of Chemistry 23(1), 41-46 (2012)

[8]. A. Meche, M.C. Martins, B.E.S.N. Lofrano, C.J. Hardaway, M. Merchant and L. Verdade, Microchemical Journal 94, 171-174 (2010)

[9]. M.T. Barbour, J. Gerritsen, B.D. Snyder and J.B. Stribling, EPA 841-B-99v002, Second Edition, U.S. Environmental Protection Agency, Office of Water, Washington D.C, (1999)
[10]. R. Munoz-Olivas, C. Camara, in: Trace Element Speciation for Environment, Food and Health, The Royal Society of Chemistry, 331-353 (2001)

[11]. U. Celik and J. Oehlenschlager, Food Control 18, 258261, (2007)

[12]. H.A. Schroeder, The Trace Elements and Nutrition, Faber and Faber, London, 1973

[13]. H. Agah, M. Leermakers, M. Elskens, S.M.R. Fatemi and W. Baeyens, Environ. Monit. Assess. 157, 499-514 (2009)

[14]. T. Vehanen and M. Lahti, Ecological Freshwater Fish 12, 203-215 (2003)

[15]. J. Carol, L. Zamora and E. Garcia-Berthou, Ecology of freshwater fish, 16 (3), 450-456 (2007)

[16]. S. Subotić, S. Spasić , Ž. Višnjić-Jeftić, A. Hegediš, J. Krpo-Ćetković, B. Mićković, S.Skorić and M. Lenhardt, Ecotoxicology and Environmental Safety 98, 196-202 (2013)

[17]. R. Kenšová, O. Čelechovská, J. Doubravová and Z. Svobodová, Acta Veterinary Brno 79, 335-345, (2010)

[18]. P. Maršálek, Z. Svobodová and T. Randák, Acta Veterinary Brno 75, 579-585 (2006)

[19]. Z. Svobodová, J. Máchová, B. Vykusová and V. Piačka, Methods RIFCH Vodňany 49, 18 (1996)

[20]. J. Marrugo-Negrete, J.O. Verbel, E.L. Ceballos and L.N. Benitez, Environ Geochem Health 30, 21-30 (2008)

[21]. L. Lacerda, E. Bidone, A. Guimaraes and W. Pfeiffer, Annais da Academia Brasilieria de Ciências 66, 373379 (1994)

[22]. J. Cibulka, E. Domažlická, J. Kozák, J. Kubizňáková, P. Mader, E. Machálek, B. Maňkovská, J. Musil, J. Pařízek, J. Píša, H. Pohunková, H. Reisnerová and Z. Svobodová Academia Praha, 83-104 (1991)

[23]. *** Anonymous, Darjaven Vestnik, 08 October 2004, Issues 88 (2004)

[24]. *** FAO/WHO, Summary of Evaluations Performed by the Joint FAO/WHO Expert Committee on Food Additives (JECFA 1956- 2003)", ILSI Press International Life Sciences Institute 2004 (2004)

[25]. Á. Altindağ and S. Yiğit, Chemosphere 60, 552-556 (2005)

[26]. J. Mattusch and R. Wennrich, Mikrochim. Acta 151, 137-139 (2005)

[27]. J.C. Ng, Environmental Chemistry 2, 146-160 (2005)

[28]. W.R. Cullen and K.J. Reimer, Chem. Rev. 89, 713-764 (1989)

[29]. J.S. Edmonds and K.A. Francesconi, Marine Pollution Bulletin 27, 665-674 (1993)

Submitted: May $20^{\text {th }} 2014$ Accepted in revised form June $23^{\text {th }} 2014$ 